\title{
Influence of conjugated linoleic acids and vitamin E on biochemical, hematological, and immunological variables of dairy cows during the transition period
}

\author{
S. Schäfers, ${ }^{*}$ D. von Soosten, ${ }^{*}$ U. Meyer, ${ }^{*}$ C. Drong, ${ }^{*}$ J. Frahm, ${ }^{* 1}$ A. Tröscher, $†$ W. Pelletier,† H. Sauerwein, $\ddagger$ \\ and S. Dänicke* \\ *Institute of Animal Nutrition, Friedrich-Loeffler-Institut (FLI), Federal Research Institute for Animal Health, Bundesallee 50, 38116 Braunschweig, \\ Germany \\ †BASF SE, Chemiestraße 22, 68623 Lampertheim, Germany \\ łInstitute of Animal Science, Physiology \& Hygiene Unit, University of Bonn, Katzenburgweg 7, 53115 Bonn, Germany
}

\begin{abstract}
The objective of this experiment was to determine the effects of conjugated linoleic acid (CLA) and vitamin E as well as their interaction on biochemical and hematological variables and on leukocyte populations and their functionality. We assigned 59 German Holstein cows between the 2nd and 9th lactation to 4 dietary groups in a $2 \times 2$ factorial design with the factors CLA and vitamin E. Six weeks before calving the cows had a BCS of 3.7 to provoke a higher risk of developing ketosis, which might impair their immune function. Blood samples for analyses were taken on $\mathrm{d}-42,-14,-7$, $-3,1,3,7,10,14,21,28,35,42,56$, and 70 relative to parturition. Furthermore, peripheral blood mononuclear cells were cultured on $\mathrm{d}-42,-7,1,7,14,28$, and 70 relative to calving. Most variables were characterized by a high variation between $\mathrm{d} 7$ antepartum and $\mathrm{d} 7$ postpartum. Treatments did not elicit any effect, with the exception of vitamin E, which increased serum urea concentrations and decreased monocyte percentages. Haptoglobin, aspartate-aminotransferase, red blood cell count, leukocyte percentage and populations, as well as peripheral blood mononuclear cells were influenced by parity. In conclusion, the impairment of immune function caused by calving was more severe in cows in $\geq 3 \mathrm{rd}$ parity than in younger cows. However, neither vitamin E nor CLA supplementation was successful to stabilize parity or parturition related variance in hematological and immunological traits.
\end{abstract}

Key words: dairy cow, conjugated linoleic acid, vitamin $\mathrm{E}$, immune function

Received September 12, 2017

Accepted September 30, 2017.

${ }^{1}$ Corresponding author: jana.frahm@fli.de

\section{INTRODUCTION}

During the transition period, 3 wk before until 3 wk after calving (Grummer et al., 1995), dairy cows are subjected to various endocrinological and metabolic changes. According to Mallard et al. (1998), these changes are accompanied by a decreased immune response. As a consequence, production diseases show the highest incidence in early lactation (Goff and Horst, 1997; LeBlanc et al., 2006). As Lacetera et al. (2005) described, cows, especially over-conditioned cows, are prone to immune suppression and resulting health disorders. After parturition, transitional dairy cows are in a state of a negative energy balance (Grummer et al., 1995) due to the onset of lactation and a decreased DMI. This negative energy balance is accompanied by lipid mobilization, leading to elevated blood concentrations of fatty acids. Due to a relative small amount of oxaloacetate, fatty acids can only partly be metabolized by the liver and, consequently, ketone bodies are produced. Schulz et al. (2014) proved that over-conditioned cows at calving are more prone to lipomobilization and have higher fatty acid concentrations as a result. Contreras and Sordillo (2011) discovered that the function of neutrophils and leukocytes might be impaired due to increased concentrations of fatty acids and ketone bodies. Lacetera et al. (2004) observed in heifers that enhanced fatty acid concentrations decreased proliferation as well as secretion of antibodies and cytokines of lymphocytes. According to Scalia et al. (2006), high fatty acid concentrations are associated with respiratory burst activities, leading to a decreased cell viability and increased necrosis rates in PMNL in vitro. Furthermore, the chemotaxis of leukocytes is impaired by high concentrations of BHB in vitro (Suriyasathaporn et al., 1999). Hoeben et al. (1997) investigated the influence of normal and subketotic BHB concentrations on the respiratory burst activity of PMNL in vitro and observed that it is impaired by high BHB concentrations. It is 
consequently suggested by Hoeben et al. (1997) that elevated $\mathrm{BHB}$ concentrations might be partly responsible for the higher incidence of infections during the transition phase. Sordillo and Aitken (2009) proposed that oxidative stress might be another risk factor further impairing the immune system in dairy cows. Oxidative stress is defined as the imbalance between the production of different reactive oxygen species (ROS) and the antioxidant mechanisms in the organism (Betteridge, 2000). According to Miller et al. (1993), damage of lipids, proteins, polysaccharides, and DNA molecules might occur as a result of oxidative stress and might therefore be responsible for altered cell functions. On the other hand, the production of different ROS by the PMNL is a physiological protection mechanism against infectious diseases. According to Dahlgren and Karlsson (1999), this reaction is mediated by the NADPH oxidase; however, the ROS production in transition cows is elevated up to a certain level, where the antioxidant mechanisms might be depleted (Sordillo and Aitken, 2009). Additionally, it has been observed that high-conditioned cows are especially vulnerable to oxidative stress during the transition period (Bernabucci et al., 2005). Vitamin $\mathrm{E}$ has been proven to elicit antioxidant activities by reacting with peroxyl radical and thereby protecting polyunsaturated fats (Burton and Traber, 1990). According to Rimbach et al. (2002), vitamin E influences different inflammatory cell signaling pathways and acts as a ligand at the peroxisome proliferator activating receptor (PPAR)- $\gamma$, whereby it is involved in the expression of different antioxidative enzymes (Nakamura and Omaye, 2010). BassaganyaRiera et al. (2002) and O'Shea et al. (2004) reported that CLA interact with PPAR- $\gamma$ as well. According to Chen et al. (2012), supplementation with CLA leads to an enhanced storage of vitamin $\mathrm{E}$ in the tissue. Furthermore, CLA may increase the secretion of vitamin E via milk (Gessner et al., 2015) and raise the vitamin E transport capacity of cholesterol (Schäfers et al., 2017b). Studies in humans (Albers et al., 2003; Song et al., 2005) showed that CLA neither affects lymphocyte populations nor does it influence the proliferation of unstimulated or concanavalin A (Con A)-stimulated peripheral mononuclear blood cells (PBMC; Nugent et al., 2005). Kelley et al. (2002) reported no alteration after supplementation with both CLA isomers on the white blood cell profile in mice. Renner et al. (2013) observed that CLA inhibited proliferation of PBMC dose dependently.

Our objective was to evaluate ex vivo and in vivo the influence of CLA and vitamin $\mathrm{E}$ on biochemical and hematological variables, as well as on populations and functionality of immune cells from dairy cows during the transition period. As we have shown, CLA increases the transport capacity of lipoproteins, resulting in higher vitamin E concentrations per lipoprotein. Consequently, we hypothesized that a combined treatment with CLA and vitamin $\mathrm{E}$ would attenuate the reduction of vitamin $\mathrm{E}$ in the blood, which is caused by reduced cholesterol concentrations shortly after parturition. In addition, we aimed to compare the ability of pluriparous cows from different parities to cope with the stress caused by the event of parturition.

\section{MATERIALS AND METHODS}

The study was conducted at the experimental station of the Institute of Animal Nutrition, Friedrich-LoefflerInstitut in Braunschweig, Germany. The experiment was carried out in accordance with the German Animal Welfare Act approved by the LAVES (Lower Saxony State Office for Consumer Protection and Food Safety, Germany).

\section{Experimental Design}

The whole study design is presented in detail in Schäfers et al. (2017a). Briefly, 59 pluriparous German Holstein cows were allocated to 4 treatment groups 8 wk antepartum (a.p.). We used an animal model established by Schulz et al. (2014), consisting of a high concentrate proportion a.p., a high BCS at calving, and a decelerated increase of concentrate proportion postpartum (p.p.), a combination suitable to induce susceptibility to lipomobilization. The treatment groups received either $8.4 \mathrm{~g}$ of trans-10, cis-12 and $8.4 \mathrm{~g}$ of cis-9,trans-11 CLA/d (BASF Lutrell; CLA group, $\mathrm{n}$ $=16$ ) or 2,327 IU of vitamin E/d (BASF Lutavit E 50; VE group, $\mathrm{n}=15$ ) or both supplements (CLA + VE, $\mathrm{n}=12)$. The control group $(\mathbf{C O N} ; \mathrm{n}=16)$ as well as the vitamin E group received a control fat supplement for caloric balance. All supplements were given from d 42 a.p. until d 70 p.p. During the whole experiment, animals were provided ad libitum with a standardized partial mixed ration by self-feeding stations (type RIC, Insentec B.V., Marknesse, the Netherlands). The different concentrates were administered via computerized self-feeding stations (Insentec B.V.). The ingredients and chemical composition of the feedstuffs are presented in Table 1 . The study was divided into 3 periods: period 1 from d 42 a.p. until the day of calving, period 2 from calving until d 21 p.p., and period 3 until d 70 p.p.

\section{Experimental Animals}

In the CON group, 10 cows were in the second ( $\mathbf{P a}$ 1) and 6 cows in the third or higher parity $(\mathbf{P a} \mathbf{2})$. In 
Table 1. Ingredients and chemical composition of concentrate and roughage during the experimental period from d 42 antepartum until d 70 postpartum

\begin{tabular}{|c|c|c|c|c|c|c|c|}
\hline Item & \multicolumn{5}{|c|}{ Concentrate $^{1}$} & \multicolumn{2}{|c|}{ Roughage $^{2}$} \\
\hline Wheat & 41 & 41 & 41 & 41 & 41 & & \\
\hline Dried sugarbeet pulp & 30.3 & 24.95 & 26.05 & 29.55 & 30.5 & & \\
\hline Rapeseed meal & 20 & 20 & 20 & 20 & 20 & & \\
\hline Soybean meal & 6.5 & 6.5 & 6.5 & 6.5 & 6.5 & & \\
\hline Vitamin E & - & 0.05 & 0.05 & 0.75 & - & & \\
\hline Vitamin/mineral premix $^{8}$ & - & 2.0 & 2.0 & - & 2.0 & & \\
\hline Vitamin/mineral premix $^{9}$ & 2.0 & - & - & 2.0 & - & & \\
\hline Calcium carbonate & 0.2 & - & - & 0.2 & - & & \\
\hline \multicolumn{8}{|l|}{ Chemical analysis ( $\mathrm{g} / \mathrm{kg}$ of DM, unless noted) } \\
\hline $\mathrm{DM}(\mathrm{g} / \mathrm{kg})$ & 879 & 884 & 883 & 886 & 875 & 340 & 302 \\
\hline Crude ash & 64 & 67 & 57 & 66 & 59 & 36 & 112 \\
\hline \multicolumn{8}{|l|}{ Energy $^{11}(\mathrm{MJ} / \mathrm{kg}$ of DM$)$} \\
\hline $\mathrm{ME}$ & 12.9 & 13.4 & 13.6 & 12.9 & 13.0 & 10.9 & 9.8 \\
\hline $\mathrm{NE}_{\mathrm{L}}$ & 8.2 & 8.6 & 8.6 & 8.2 & 8.2 & 7.0 & 5.4 \\
\hline DL- $\alpha$-tocopheryl acetate (IU/kg of DM) & - & 217 & 188 & 2,453 & - & - & - \\
\hline trans-10, cis-12 CLA ( $\mathrm{g} / \mathrm{kg}$ of DM) & $<0.01$ & 4.7 & $<0.01$ & $<0.01$ & - & - & - \\
\hline
\end{tabular}

${ }^{1}$ Concentrate allocation (original substance) per group before parturition: control group $=2 \mathrm{~kg}$ of SF, $1 \mathrm{~kg}$ of LAC; CLA group $=2 \mathrm{~kg}$ of CLA, $1 \mathrm{~kg}$ of LAC; VE group $=2 \mathrm{~kg}$ of SF, $1 \mathrm{~kg}$ of vitamin E; CLA + VE group $=2 \mathrm{~kg}$ of CLA, $1 \mathrm{~kg}$ of vitamin E. Concentrate allocation (original substance) per group after parturition: control group $=2 \mathrm{~kg}$ of SF, $1 \mathrm{~kg}$ of LAC; CLA group = $2 \mathrm{~kg}$ of CLA, $1 \mathrm{~kg}$ of LAC; VE group: $2 \mathrm{~kg}$ of $\mathrm{SF}, 1 \mathrm{~kg}$ of vitamin E; CLA + VE group: $2 \mathrm{~kg}$ of CLA, $1 \mathrm{~kg}$ of vitamin E.

${ }^{2} 50 \%$ maize silage, $50 \%$ grass silage on a DM basis.

${ }^{3}$ Concentrate for lactation (LAC).

${ }^{4}$ CLA concentrate.

${ }^{5}$ Silafat (SF; BASF SE, Lampertheim, Germany) concentrate.

${ }^{6}$ Vitamin E concentrate.

${ }^{7}$ Concentrate for dry cows.

${ }^{8}$ Ingredients per $\mathrm{kg}$ of mineral feed: $50 \mathrm{~g}$ of Ca; $120 \mathrm{~g}$ of Na; $70 \mathrm{~g}$ of P; $50 \mathrm{~g}$ of Mg; $7 \mathrm{~g}$ of Zn; $4.8 \mathrm{~g}$ of Mn; $1.3 \mathrm{~g}$ of $\mathrm{Cu} ; 100 \mathrm{mg}$ of I; $50 \mathrm{mg}$ of Se; $35 \mathrm{mg}$ of $\mathrm{Co} ; 800,000 \mathrm{IU}$ of vitamin $\mathrm{A} ; 100,000 \mathrm{IU}$ of vitamin $\mathrm{D}_{3}$.

${ }^{9}$ Ingredients per $\mathrm{kg}$ of mineral feed: $140 \mathrm{~g}$ of Ca; $120 \mathrm{~g}$ of Na; $70 \mathrm{~g}$ of P; $40 \mathrm{~g}$ of Mg; $6 \mathrm{~g}$ of Zn; $5.4 \mathrm{~g}$ of Mn; $1 \mathrm{~g}$ of Cu; $100 \mathrm{mg}$ of I; $40 \mathrm{mg}$ of Se; $25 \mathrm{mg}$ of Co; 1,000,000 IU of vitamin A; 100,000 IU of vitamin $\mathrm{D}_{3}$.

${ }^{10} \mathrm{NDFOM}=\mathrm{NDF}$ determined on an OM base.

${ }^{11}$ Calculation based on equations for calculation of energy content in feedstuffs published by the GfE (2001, 2008, 2009).

the CLA group, 9 cows were in $\mathrm{Pa} 1$ and 6 in $\mathrm{Pa} 2$. For the VE group, this relationship was 10:5, whereas in the CLA + VE group 5 cows were in $\mathrm{Pa} 1$ and 7 cows in $\mathrm{Pa}$ 2. All cows were daily clinically monitored by veterinarians. Body temperature was regularly measured rectally, and animals were inspected visually with regard to their appearance (skin turgor, body control, nose excretions) and gait. Consistency of feces was also observed. Furthermore, we monitored daily feed intake of each animal individually by means of the used feeding system. In total, for 15 animals $(\mathrm{CON}$ : $\mathrm{n}=3$; CLA: $\mathrm{n}=3$; vitamin $\mathrm{E}: \mathrm{n}=5$; CLA + vitamin $\mathrm{E}: \mathrm{n}=4$ ) subclinical mastitis was detected. Cows that had to be treated medicinally were excluded from the trial.

\section{Sample Collection}

Samples of roughage feed were taken twice weekly. Concentrate samples were taken once weekly for every group. Roughage and concentrate samples were pooled to a collective sample for periods of $4 \mathrm{wk}$.

Blood samples were taken on d -42 (initial sample), and then on $\mathrm{d}-14,-7,-3,1,3,7,10,14,21,28,35$, 42,56 , and 70 relative to parturition. After morning milking and before main feeding, samples were taken from the jugular vein into serum and EDTA tubes. Additionally, blood samples were taken on d $-42,-7$, $1,7,14,28$, and 70 relative to calving into lithiumheparinized vacuum tubes (Vacuette, Greiner Bio-One 
GmbH, Frickenhausen, Germany) to culture PBMC. All blood was used for flow cytometry and analysis of hematological variables. Serum and plasma samples were centrifuged (Varifuge 3.0R, Heraeus, Osterode, Germany; $2,123 \times g, 15^{\circ} \mathrm{C}, 15 \mathrm{~min}$ ) and stored at $-80^{\circ} \mathrm{C}$ until analysis.

\section{Analyses}

Samples of partial mixed ration and concentrate were analyzed according to the standard methods defined by VDLUFA (1993; method numbers in brackets) for DM (3.1), crude ash (8.1), CP (4.1.2), ether extract (5.1.1), crude fiber (6.1.1) as well as NDF and tocopherol acetate according to a modified version of the tocopherol acetate method (Japanese Pharmacopoeia Committee, 2011). The CLA isomers were analyzed by HPLC as described in Schäfers et al. (2017b).

Serum samples were analyzed for albumin (ALB), aspartate-aminotransferase (AST), gamma-glutamyl-transferase (GGT), glutamate dehydrogenase (GLDH), protein, bilirubin, triglycerides, and urea by a photometric measuring system (Eurolyser VET CCA, Salzburg, Austria). Haptoglobin concentrations were determined using an ELISA according to Hiss et al. (2004) with a limit of detection of $0.07 \mathrm{mg} / \mathrm{mL}$. The concentrations of adiponectin were analyzed using an ELISA as described by Mielenz et al. (2013) with a limit of detection of $0.03 \mathrm{ng} / \mathrm{mL}$.

Hematological variables were analyzed in potassium-EDTA-whole blood with an automatic analyzer Celltac- $\alpha$ (MEK 6450; Nihon Kohden, Qinlab Diagnostik, Weichs, Germany). Both white and red blood cell profiles were generated. Total leukocyte count data (WBC), lymphocytes, monocytes, basophile, and neutrophile granulocytes were analyzed for the white blood cell profile, whereas the red blood cell profile consisted of red blood cell count (RBC), hemoglobin, hematocrit, mean corpuscular volume (MCV), mean corpuscular hemoglobin, and mean corpuscular hemoglobin concentration.

Isolation of PBMC was performed according to a method described by Renner et al. (2011). Briefly, heparinized whole blood was diluted 1:1 with PBS and then centrifuged at $603 \times g$ for $35 \mathrm{~min}$ at room temperature using Biocoll separation solution (Biochrom L6113, Biochrom GmbH, Berlin, Germany). The PBMC were isolated as buffy coat and analyzed for their metabolic activity and the proliferation stimulated by Con A (Sigma-Aldrich, Steinheim, Germany) with an AlamarBlue reagent (AB; AbD Serotec, Oxford, UK). Each well of a 96-well plate was filled with 100,000 cells in quintuplicates with or without $0.5 \mu \mathrm{g}$ of Con A /well. Plates were incubated at $37^{\circ} \mathrm{C}$ with $5 \% \mathrm{CO}_{2}$ for 69.5 $\mathrm{h}$ and then centrifuged at $200 \times g$ for 5 min at room temperature (Hettich Universal 320, Andreas Hettich GmbH \& Co.KG, Tuttlingen, Germany). After centrifugation, $100 \mu \mathrm{L}$ of the supernatants were removed from each well and $11 \mu \mathrm{L}$ of $\mathrm{AB}$ (dilution ratio 1:10) were added. After further incubation for $2.5 \mathrm{~h}$ at $37^{\circ} \mathrm{C}$, the reduction of nonfluorescent resazurin to fluorescent resorufin, which is performed by metabolically active cells, was measured photometrically (Tecan infinite M200, Grödig, Austria) at $540 \mathrm{~nm}$ of excitation and $590 \mathrm{~nm}$ of emission.

To phenotype the T-cell populations, whole blood was either stained with monoclonal antibodies for CD4+ (mouse anti-bovine CD4:fluorescein isothiocyanate, Bio-Rad Laboratories Inc., Hercules, CA) and CD8+ (mouse anti-bovine CD8:phycoerythrin, Bio-Rad Laboratories Inc.) or with isotype controls (mouse IgG2a negative control:RPE or mouse IgG2b: fluorescein isothiocyanate negative control, Bio-Rad Laboratories Inc.). Samples were incubated at room temperature for $30 \mathrm{~min}$. After incubation, lysis buffer (BD Biosciences, Franklin Lakes, NJ) was applied for 10 min to lyse the red blood cells. Samples were centrifuged (Heraeus Varifug 3.0R; $200 \times g, 4^{\circ} \mathrm{C}, 5 \mathrm{~min}$ ), then resuspended in HEPES-buffered saline and measured by the FACSCanto II flow cytometer (BD Biosciences). The different populations of lymphoid cells were identified using distinct side- and forward-scattering characteristics. Measuring was performed until at least 10,000 lymphocytes were stored in list mode data files. The BD FACSDiva software (BD Biosciences) was used to adjust the spillover of the fluorochromes fluorescein isothiocyanate and phycoerythrin. The quantity of each T-cell phenotype was estimated with the help of the percentages obtained by the flow cytometer.

The capacity of granulocytes to induce oxidative burst and the release of ROS was assessed by measuring the oxidation of nonfluorescent dihydrorhodamine 123 (DHR) to fluorescent rhodamine 123 (R123) by means of hydrogen peroxide with the flow cytometer. The fraction of PMNL, which converted DHR to R123 by the production of ROS, is represented by the R123+ population. The mean conversion of DHR per cell can be measured by the mean fluorescence intensity (MFI). Either $40 \mu M$ DHR (Molecular Probes, Eugene, OR) or $40 \mu M$ DHR and $20 \mathrm{n} M$ phorbol myristate acetate (Sigma-Aldrich) were added to whole blood samples. Samples were then incubated at $37^{\circ} \mathrm{C}$ for 15 min. Lysis buffer (BD Pharm Lyse, BD Biosciences) was applied for 10 min to lyse red blood cells. Thereafter, cells were washed with HEPES-buffered saline. Measurement was done dually by the FACSCanto II (BD Biosciences) until at least 10,000 granulocytes were measured. Granulocytes were defined by 
their size and granularity by using side and forward scattering characteristics.

\section{Calculations and Statistical Analysis}

To calculate the proliferation of the PBMC in vitro, the stimulation index (SI) was used:

$$
\mathrm{SI}=(\text { fluorescence of cells stimulated with Con A)/ }
$$

(fluorescence of unstimulated cells).

The CD4+-to-CD8+ ratio was calculated according to the formula

$$
\begin{gathered}
\text { CD4:CD8 }=\text { (percentage of CD4+)/ } \\
\text { (percentage of CD8+). }
\end{gathered}
$$

Trevisi et al. (2013) had described a high correlation of vitamin $\mathrm{E}$ and cholesterol as an indication of circulating lipoproteins. On that basis, Schäfers et al. (2017b) used ratios of vitamin $\mathrm{E}$ to cholesterol for calculating correlations to vitamin $\mathrm{E}$ levels in blood.

Statistical analyses were performed using the SAS software package (version 9.4; SAS Institute Inc., Cary, NC). The procedure MIXED for repeated measures was used with an autoregressive covariance structure (Littell et al., 1998). The fixed effects in the model were CLA, vitamin E, time, parity, and the interaction between them. Each cow within treatment was considered to be a random effect. The day or week of sampling was a repeated measure. For all variables, the value of the d -42 sample was used as a covariate. Data are reported as least squares means \pm standard error of the mean; $P$-values $>0.05$ and $\leq 0.10$ were considered to be a trend, whereas $P$-values $\leq 0.05$ were considered to be statistically significant after Tukey post-hoc test.

\section{RESULTS}

Samples taken on d 42 a.p. displayed for all presented variables showed no significant differences between groups. Selected variables of clinical chemistry are presented in Figure 1. During the course of the trial, haptoglobin concentrations were lower in $\mathrm{Pa} 1$ than in $\mathrm{Pa} 2(0.70 \pm 0.16$ vs. $1.38 \pm 0.17 \mathrm{mg} / \mathrm{mL} ; P=0.006)$ and were influenced by time. The concentrations of adiponectin (Table 2 ) were influenced by time only $(P$ $<0.001$ ), showing a drop toward day of calving. The GLDH activity (not presented) was $14.0 \pm 8.94 \mathrm{U} / \mathrm{L}$; for this variable, we did not detect any influence of time, treatment, or parity. Over the course of the trial, AST activity (Table 2) was higher in $\mathrm{Pa} 2$ than in $\mathrm{Pa} 1$
$(97.7 \pm 6.01$ vs. $81.3 \pm 5.39 \mathrm{U} / \mathrm{L}, P=0.049)$ and was influenced by time $(P<0.001)$, showing peaks at $\mathrm{d} 7$ and 14 p.p. The GGT activity in $\mathrm{Pa} 1$ was $27.6 \pm 1.14$ $\mathrm{U} / \mathrm{L}$, whereas cows in $\mathrm{Pa} 2$ showed mean activities of $31.2 \pm 1.26 \mathrm{U} / \mathrm{L}$. Although we observed an influence of time $(P<0.001)$ for GGT activity, the difference between parities was only a trend $(P=0.054)$. Pearson correlation coefficients between GGT and cholesterol were significant for all groups except the CLA + VE group (control group: $\mathrm{r}=0.27, P=0.005$; VE group: $\mathrm{r}=0.31, P=0.002$; CLA group: $\mathrm{r}=0.32, P=0.001)$. Concentrations of triglycerides (Table 2) dropped during the course of the trial $(P<0.001)$; we observed the lowest concentrations of triglycerides on $\mathrm{d} 7$ p.p. The protein concentration (not presented) on d 42 a.p. was $69.7 \pm 1.46 \mathrm{~g} / \mathrm{L}$, it dropped to $65.9 \pm 1.67 \mathrm{~g} / \mathrm{L}$ at $\mathrm{d} 1$ p.p. and increased thereafter to $77.0 \pm 1.44 \mathrm{~g} / \mathrm{L}$ on $\mathrm{d} 70$ p.p., being influenced by time $(P<0.001)$. The concentrations of ALB (Table 2$)$ were influenced by time $(P=$ 0.023); ALB concentrations increased from d 42 a.p. to reach a peak at d 1 p.p. and decreased again beginning on $\mathrm{d} 7$ p.p.. The urea concentrations (Table 2) were higher in cows treated with vitamin $\mathrm{E}$ than in those not treated with vitamin $\mathrm{E}(25.65 \pm 1.28$ vs. $20.19 \pm 1.15$ $\mathrm{mg} / \mathrm{dL}, P=0.003)$ and were influenced by time $(P<$ 0.001). Expressions of high urea concentration a.p. and low concentrations p.p. were caused by the employed animal model, which included dietary protein excess a.p. and low protein p.p. Bilirubin concentrations (Figure 1) showed an interaction between time, treatment, and parity $(P=0.005)$, which is reflected by cows in Pa 2, except for the control group peaking on d 1 p.p.; however, the peak occurred on d 3 p.p for cows in $\mathrm{Pa}$ 1. Pearson correlation coefficients between vitamin $\mathrm{E}$ in blood and bilirubin were not significant and slope of the regression lines did not differ between treatment groups. Pearson correlation coefficients between GGT and bilirubin were significant only for the CLA ( $\mathrm{r}=$ $0.21, P=0.037)$ and CLA + VE group $(\mathrm{r}=0.38, P<$ $0.001)$.

Figure 2 shows the red blood cell profile. For $\mathrm{Pa} 1$, $\mathrm{RBC}$ was $5.93 \pm 0.07 \times 10^{6} / \mu \mathrm{L}$ over the course of the trial, whereas cows in $\mathrm{Pa} 2$ showed a mean $\mathrm{RBC}$ of $5.40 \pm 0.08 \times 10^{6} / \mu \mathrm{L}$. Time $(P<0.001)$ and parity $(P=0.005)$ had an influence on RBC. In cows in $\mathrm{Pa}$ 1 , HGB concentration was $9.93 \pm 0.10 \mathrm{~g} / \mathrm{dL}$, whereas we observed a HGB concentration of $10.2 \pm 0.11 \mathrm{~g} / \mathrm{dL}$ in cows in $\mathrm{Pa} 2$. However, the influence of parity was only a trend $(P=0.062)$, whereas time had a significant influence $(P<0.001)$. Progressions of hematocrit were analogous, with time eliciting an influence $(P<$ $0.001)$ and parity showing a trend $(P=0.075)$. The MCV values in animals treated with vitamin $\mathrm{E}$ were higher $(61.8 \pm 0.47$ vs. $53.5 \pm 0.41 \mathrm{fL})$ and showed a 


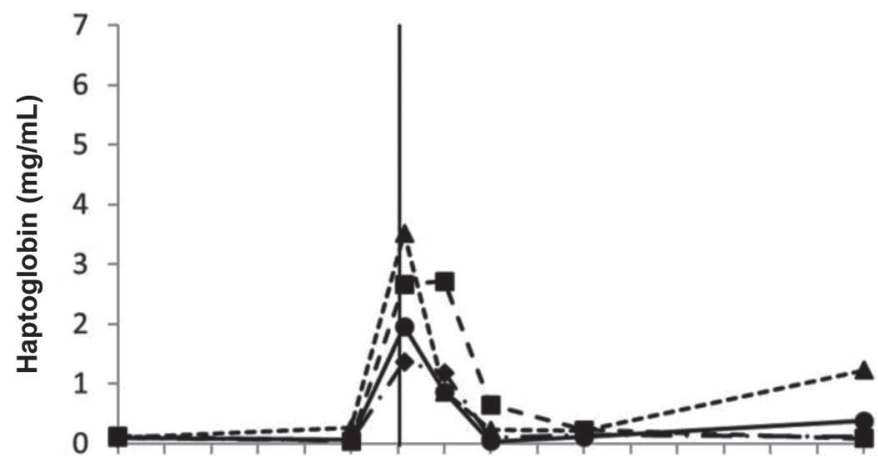

$-42-35-28-21-14-7 \quad 0 \quad 7 \quad 14212835424956 \quad 6370$
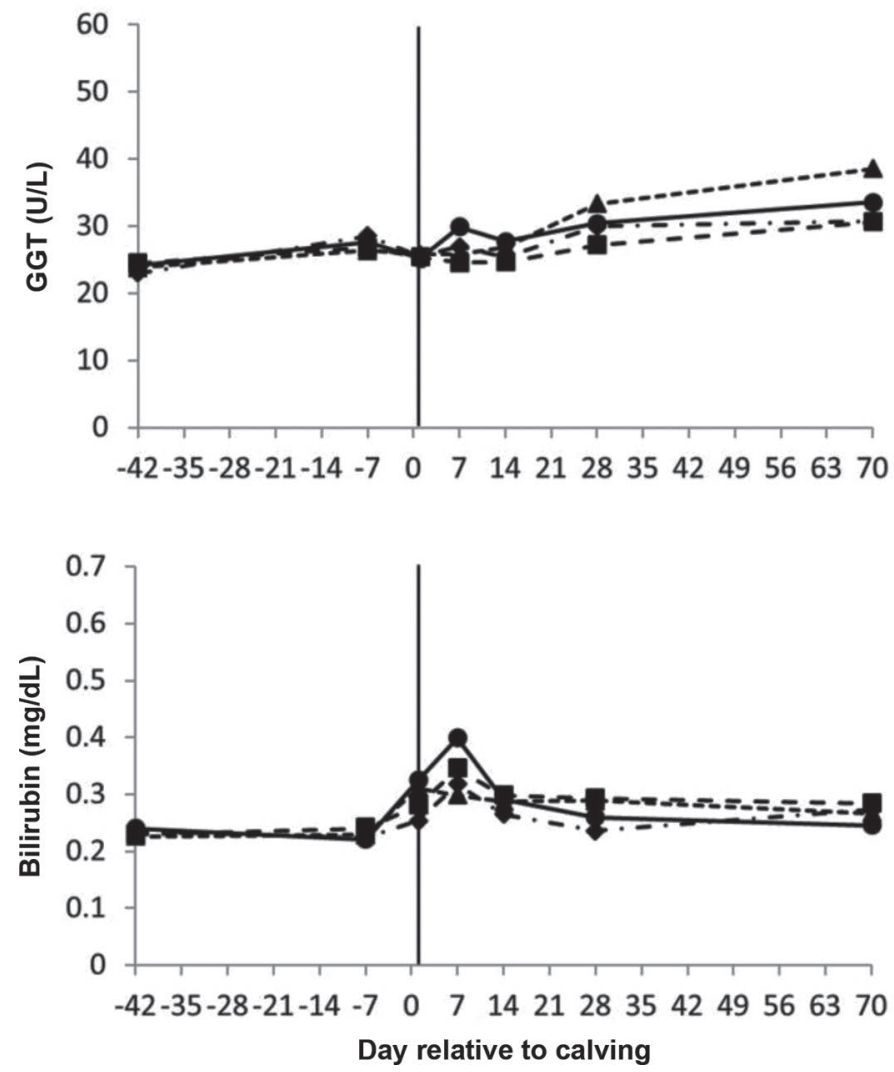
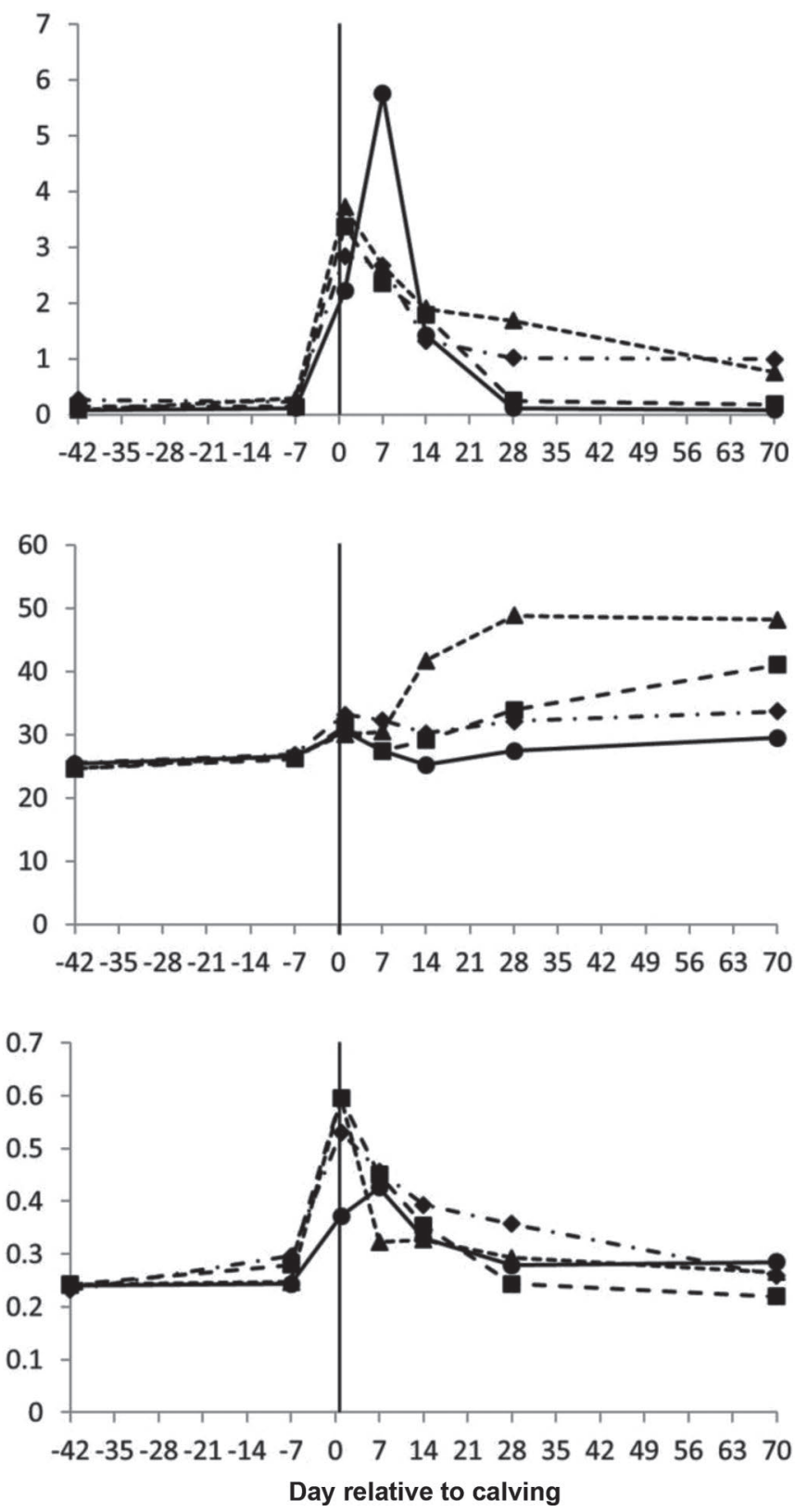

Figure 1. Variables of clinical chemistry of cows in second (left side) and $\geq$ third (right side) parity (LSM). Groups included a control group ( $\mathrm{n}=16 ; \boldsymbol{\bullet}$, solid line), a CLA group receiving $8.4 \mathrm{~g}$ of trans-10,cis-12 CLA/d ( $\mathrm{n}=16 ; \mathbf{\square}$, long dashed line), a vitamin $\mathrm{E}$ group ( $\mathrm{n}=15)$ receiving $2,327 \mathrm{IU}$ of vitamin $\mathrm{E} / \mathrm{d}(\boldsymbol{\Lambda}$. short dashed line), and a group $(\mathrm{n}=12)$ receiving both treatments $(\bullet$, long dash-dotted line) from d -42 until 70 relative to calving. In the control group, 10 cows were in second and 6 in third or higher parity. In the CLA group, 9 cows were in second and 6 in third or higher parity. For the vitamin E group, this relationship was 10:5, whereas in the CLA + vitamin E group 5 cows were in second and 7 cows in third or higher parity. GGT = gamma-glutamyl-transferase.

more profound dip after calving in Pa 2 compared with animals in $\mathrm{Pa}$ 1. This is reflected by an interaction between time, treatment and parity $(P<0.001)$. The mean corpuscular hemoglobin values of the VE group in $\mathrm{Pa} 2$ were elevated on $\mathrm{d}-3,1,21,42,56$, and 70 , causing an interaction between time, treatment, and parity $(P=0.010)$. During the course of the trial the mean corpuscular hemoglobin concentration was $30.9 \pm$
$0.17 \mathrm{~g} / \mathrm{dL}$, with the CLA + VE group in Pa 1 showing elevated values on d 28 and 35 p.p., and thereby causing an interaction between time, treatment and parity $(P=0.050)$.

The white blood cell profile is presented in Figure 3; WBC increased toward calving $(P<0.001)$ and tended to be higher in animals treated with vitamin $\mathrm{E}$ than in those not treated with vitamin $\mathrm{E}\left(8.45 \pm 0.31 \times 10^{3}\right.$ vs. 
$\left.7.90 \pm 0.31 \times 10^{3} / \mu \mathrm{L} ; P=0.097\right)$. Cows in $\mathrm{Pa} 1$ had the tendency toward higher values than those in $\mathrm{Pa} 2(8.51$ \pm 0.31 vs. $\left.7.84 \pm 0.31 \times 10^{3} / \mu \mathrm{L} ; P=0.056\right)$. Percentage of lymphocytes dropped toward calving $(P<0.001)$ and was higher in $\mathrm{Pa} 1$ than in $\mathrm{Pa} 2$ (37.58 \pm 0.74 vs. $34.27 \pm 0.83 \% ; P=0.005)$. Percentage of monocytes in cows treated with vitamin $\mathrm{E}$ was decreased compared with those not treated with vitamin $\mathrm{E}(2.90 \pm 0.26$ vs. $3.69 \pm 0.31 \% ; P=0.047)$, whereas percentage of granulocytes increased toward calving $(P<0.001)$.

Figure 4 shows the evaluation of the $\mathrm{AB}$ assay. In $\mathrm{Pa} 2$, fluorescence of unstimulated cells was decreased compared with $\mathrm{Pa} 1(6,478 \pm 317$ vs. $7,825 \pm 273 ; P$ $=0.002)$. Fluorescence of stimulated PBMC of control group cows in $\mathrm{Pa} 2$ showed a drop on d 7 a.p., which is reflected by an interaction between time, treatment, and parity $(P=0.001)$. We observed an influence of time $(P<0.001)$ and parity $(P=0.004)$ on the SI. Correlation coefficient between fatty acids and SI was significant only for the VE group $(\mathrm{r}=-0.19, P=0.040)$.

Population of lymphocytes is presented in Figure 5. The CLA group in $\mathrm{Pa} 1$ showed a peak in percentage of CD4+-lymphocytes on $\mathrm{d} 1$ a.p., causing an interaction between time, treatment, and parity $(P=0.039)$. Cows

Table 2. Concentration of adiponectin (ADI), aspartate aminotransferase (AST), triglycerides (TRI), albumin (ALB), and urea in blood serum of the experimental groups in 2nd ( $\mathrm{Pa} 1$ ) and 3rd and higher parities ( $\mathrm{Pa} 2$ ) during period 1 (d 42 antepartum until calving), period 2 (d 1-21 postpartum), and period 3 (d 22-70 postpartum; LSM $)^{1}$

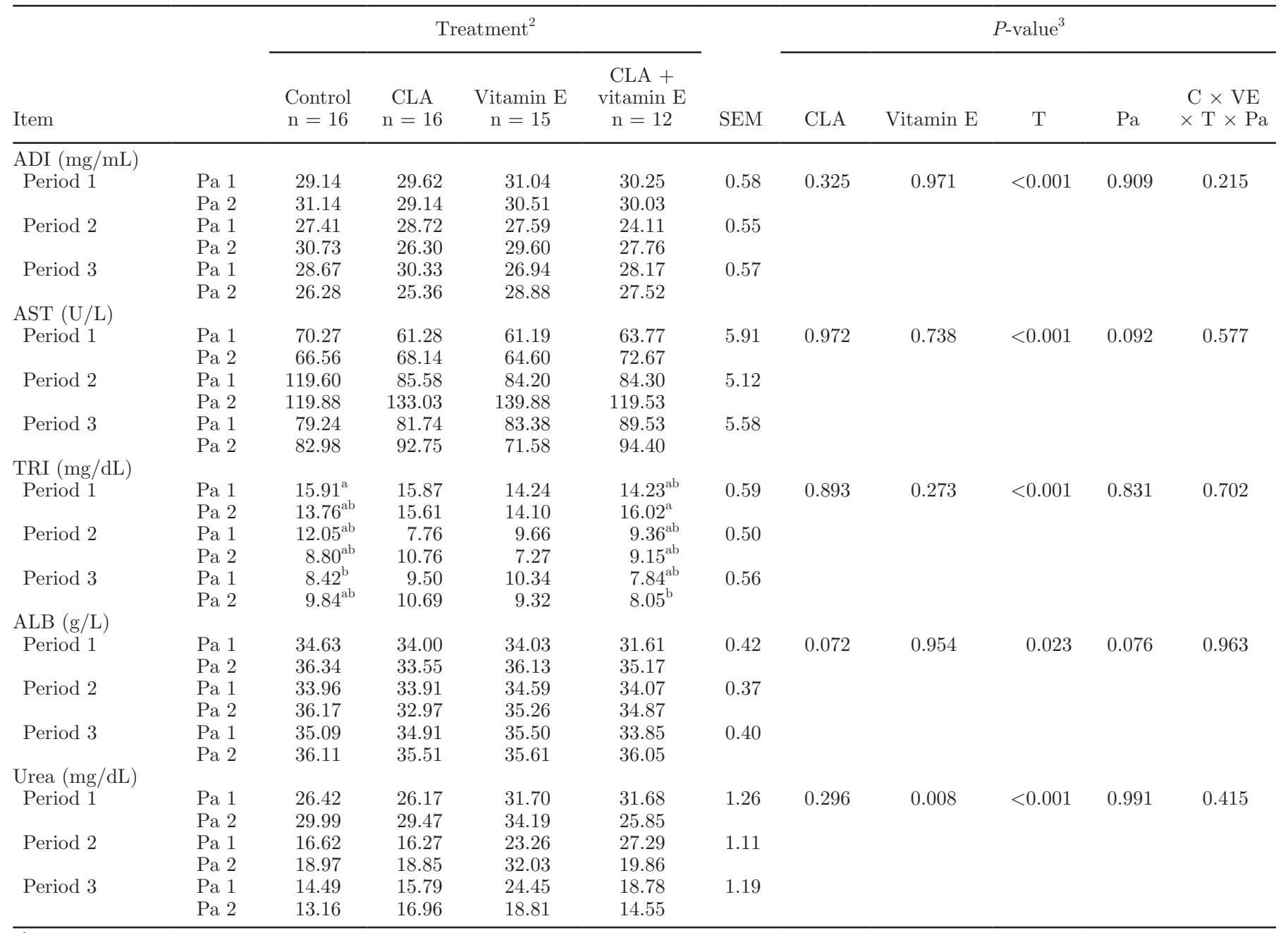

${ }^{\mathrm{a}, \mathrm{b}}$ Least squares means with different superscripts within columns differ $(P<0.05)$.

${ }^{1}$ The concentration on d 42 antepartum was used as a covariable in the statistical analysis.

${ }^{2}$ Treatment: Before calving cows were fed a concentrate proportion of $60 \%$. Postpartum, the concentrate proportion increased from 30 to $50 \%$ within 3 wh in all groups. CLA $(\mathrm{n}=16)$ and CLA + vitamin $\mathrm{E}(\mathrm{n}=12)$ received $8.4 \mathrm{~g}$ of trans-10, cis-12 CLA/d (BASF Lutrell; Ludwigshafen, Germany). Vitamin E $(\mathrm{n}=15)$ and CLA + vitamin E groups received 2,327 IU of vitamin E/d (BASF Lutavit E 50). The control group (n = 16) as well as the vitamin $\mathrm{E}$ group received $88 \mathrm{~g} / \mathrm{d}$ of a rumen-protected fat supplement.

${ }^{3} \mathrm{~T}=$ time; $\mathrm{Pa}=$ parity $\mathrm{C} \times \mathrm{VE} \times \mathrm{T} \times \mathrm{Pa}=$ interaction between CLA, vitamin $\mathrm{E}$, time, and parity. 

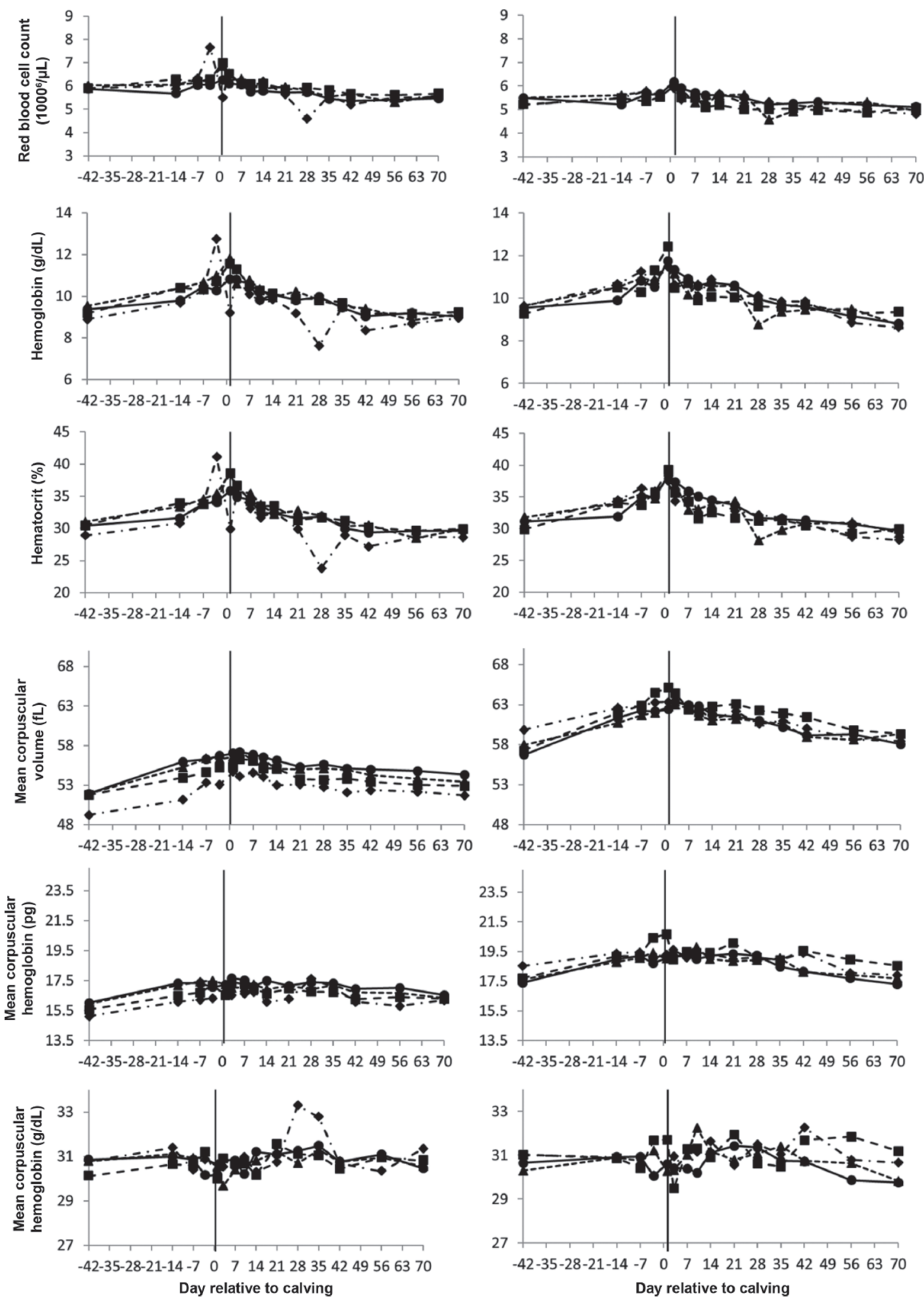

Figure 2. Red blood cell profile of whole blood of cows in second (left side) and $\geq$ third (right side) parity (LSM). Groups included a control group $(\mathrm{n}=16 ; \boldsymbol{\bullet}$, solid line), a CLA group receiving $8.4 \mathrm{~g}$ of trans-10,cis-12 CLA/d ( $=16 ; \mathbf{\square}$, long dashed line), a vitamin $\mathrm{E}$ group ( $=15)$ receiving 2,327 IU of vitamin $\mathrm{E} / \mathrm{d}(\boldsymbol{\Lambda}$, short dashed line), and a group $(\mathrm{n}=12)$ receiving both treatments $(\bullet$, long dash-dotted line) from d -42 until 70 relative to calving. In the control group, 10 cows were in second and 6 in third or higher parity. In the CLA group, 9 cows were in second and 6 in third or higher parity. For the vitamin E group, this relationship was 10:5, whereas in the CLA + vitamin E group 5 cows were in second and 7 cows in third or higher parity. 

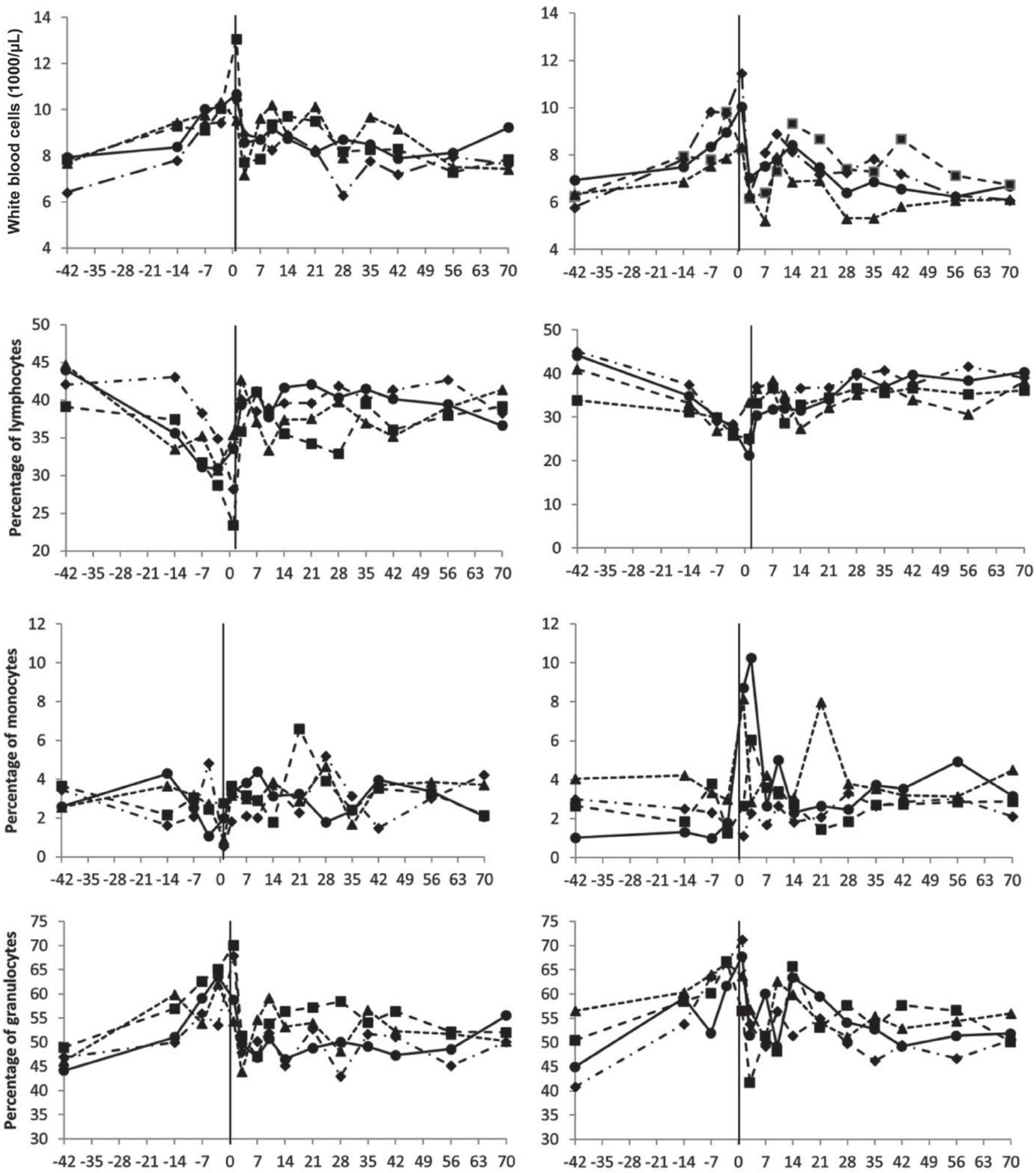

Day relative to calving

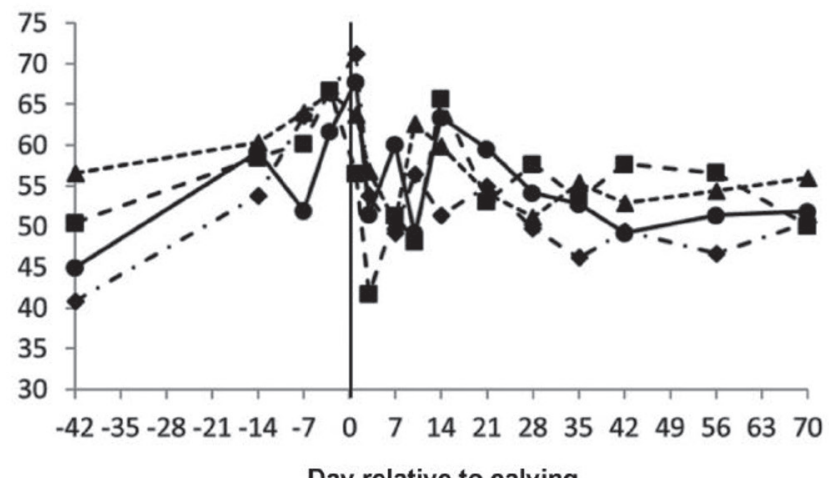

Figure 3. White blood cell profile of whole blood of cows in second (left side) and $\geq$ third (right side) parity (LSM). Groups included a control group ( $\mathrm{n}=16$;, solid line), a CLA group receiving $8.4 \mathrm{~g}$ of trans-10, cis-12 CLA/d $(\mathrm{n}=16 ; \boldsymbol{\square}$, long dashed line), a vitamin $\mathrm{E}$ group ( $\mathrm{n}=$ 15) receiving 2,327 IU of vitamin $\mathrm{E} / \mathrm{d}(\boldsymbol{\Lambda}$, short dashed line), and a group $(\mathrm{n}=12)$ receiving both treatments $(\bullet$, long dash-dotted line) from $\mathrm{d}$ -42 until 70 relative to calving. In the control group, 10 cows were in second and 6 in third or higher parity. In the CLA group, 9 cows were in second and 6 in third or higher parity. For the vitamin E group, this relationship was 10:5, whereas in the CLA + vitamin E group 5 cows were in second and 7 cows in third or higher parity. 

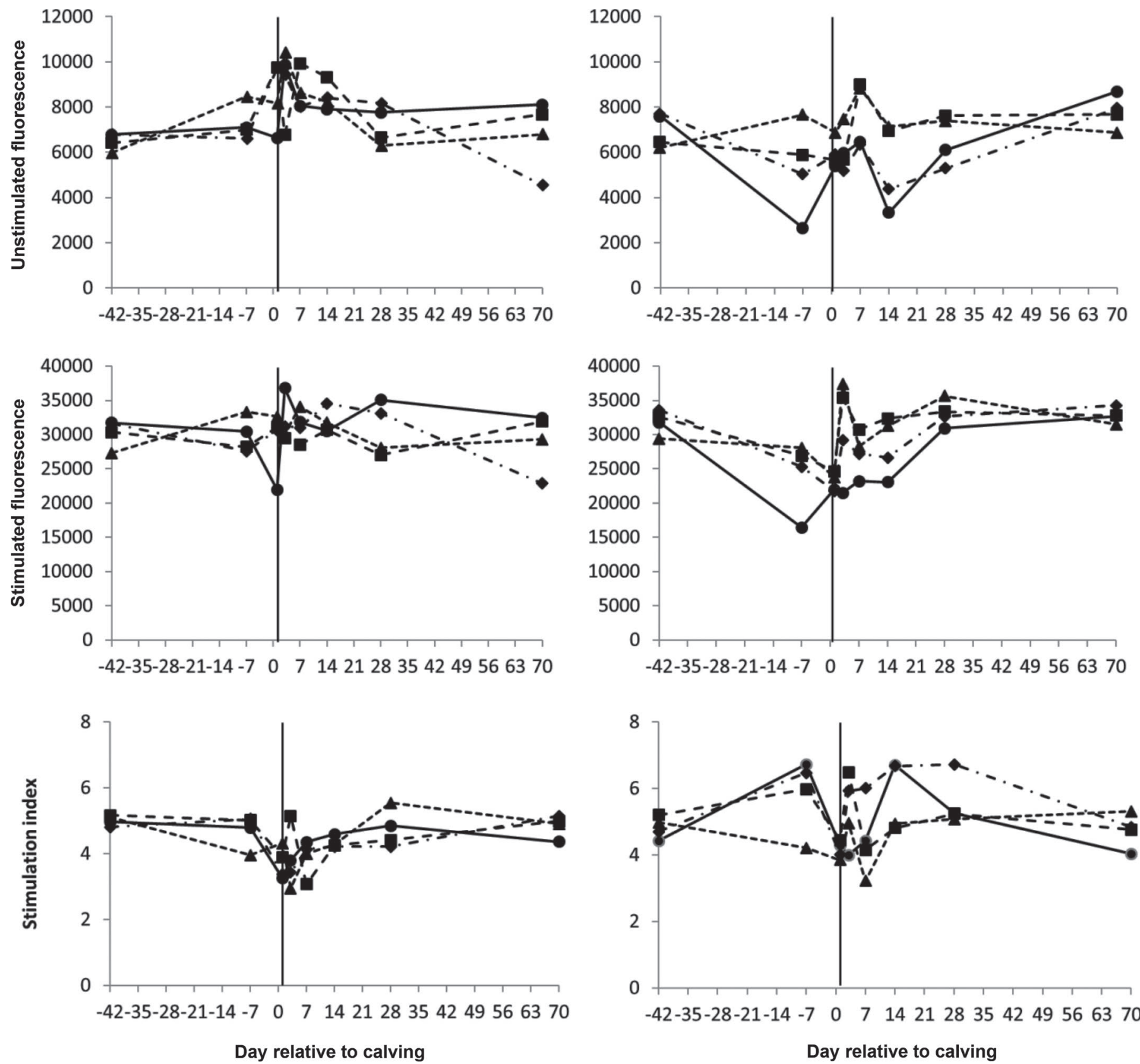

Day relative to calving

Figure 4. Activity of unstimulated and concanavalin A-stimulated peripheral mononuclear blood cells (PBMC) and resulting stimulation index of cows in second (left side) and $\geq$ third (right side) parity (LSM). Groups included a control group ( $\mathrm{n}=16$; $\bullet$, solid line), a CLA group receiving $8.4 \mathrm{~g}$ of trans-10,cis-12 CLA/d ( $\mathrm{n}=16 ; \boldsymbol{\square}$, long dashed line), a vitamin E group $(\mathrm{n}=15)$ receiving $2,327 \mathrm{IU}$ of vitamin E/d $(\boldsymbol{\Lambda}$, short dashed line), and a group $(\mathrm{n}=12)$ receiving both treatments $(\bullet$, long dash-dotted line) from $\mathrm{d}-42$ until 70 relative to calving. In the control group, 10 cows were in second and 6 in third or higher parity. In the CLA group, 9 cows were in second and 6 in third or higher parity. For the vitamin E group, this relationship was 10:5, whereas in the CLA + vitamin E group 5 cows were in second and 7 cows in third or higher parity.

in $\mathrm{Pa} 1$ had lower percentages of CD8+-lymphocytes than older cows $(10.93 \pm 0.63$ vs. $13.11 \pm 0.71 \%$, respectively; $P=0.022$ ). We detected no influence of time, treatment, or parity on the ratio of $\mathrm{CD}$ to lymphocytes.

Figure 6 shows the basal and stimulated proportion and fluorescence intensity of the R123+ population of
PMNL. Basal R123+ proportion in Pa 1 was increased compared with $\mathrm{Pa} 2(10.4 \pm 0.56$ vs. $8.2 \pm 0.63 \%$, respectively; $P=0.012)$ and decreased by $78 \%$ from $\mathrm{d} 42$ a.p. to d 1 p.p. $(P<0.001)$. The MFI of basal R123+ cells dropped $32 \%$ from d 42 to 3 a.p. $(P<0.001)$. Treatment and parity were without effect. Correlation 
coefficients between MFI of basal R123+ cells and vitamin $\mathrm{E}$ in serum were only significant for the VE group $(\mathrm{r}=-0.25, P=0.012)$. Stimulated R123+ proportion peaked on d 1 a.p. $(P=0.038)$ without influence of treatment or parity; MFI of stimulated R123+ proportion increased $29 \%$ from d 42 to 1 a.p. $(P<0.001)$.
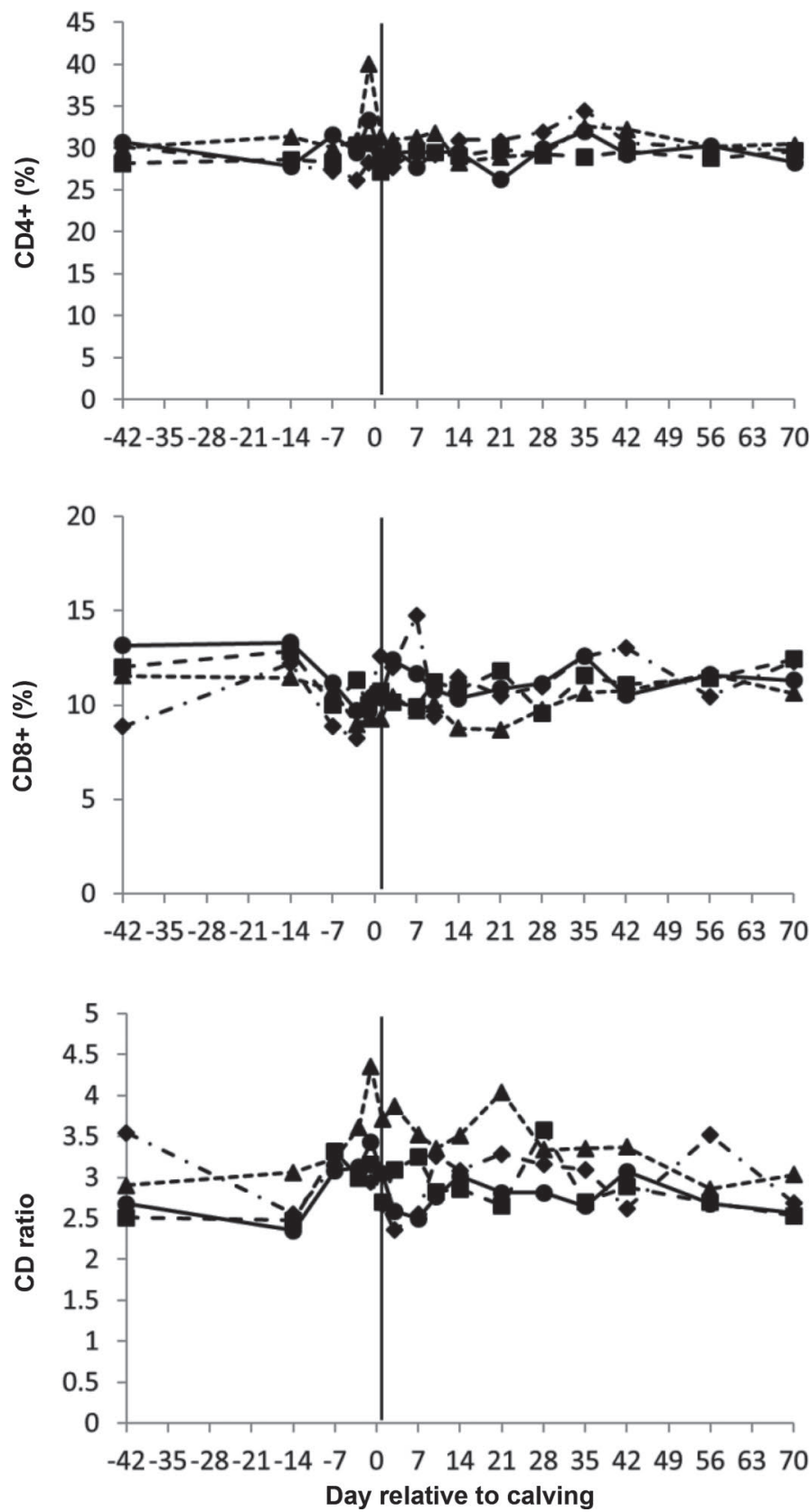

DISCUSSION

The objective of our trial was to investigate the influences of treatment with either CLA or vitamin $\mathrm{E}$ or a combination thereof on biochemical and hematological variables as well as on populations of immune cells and
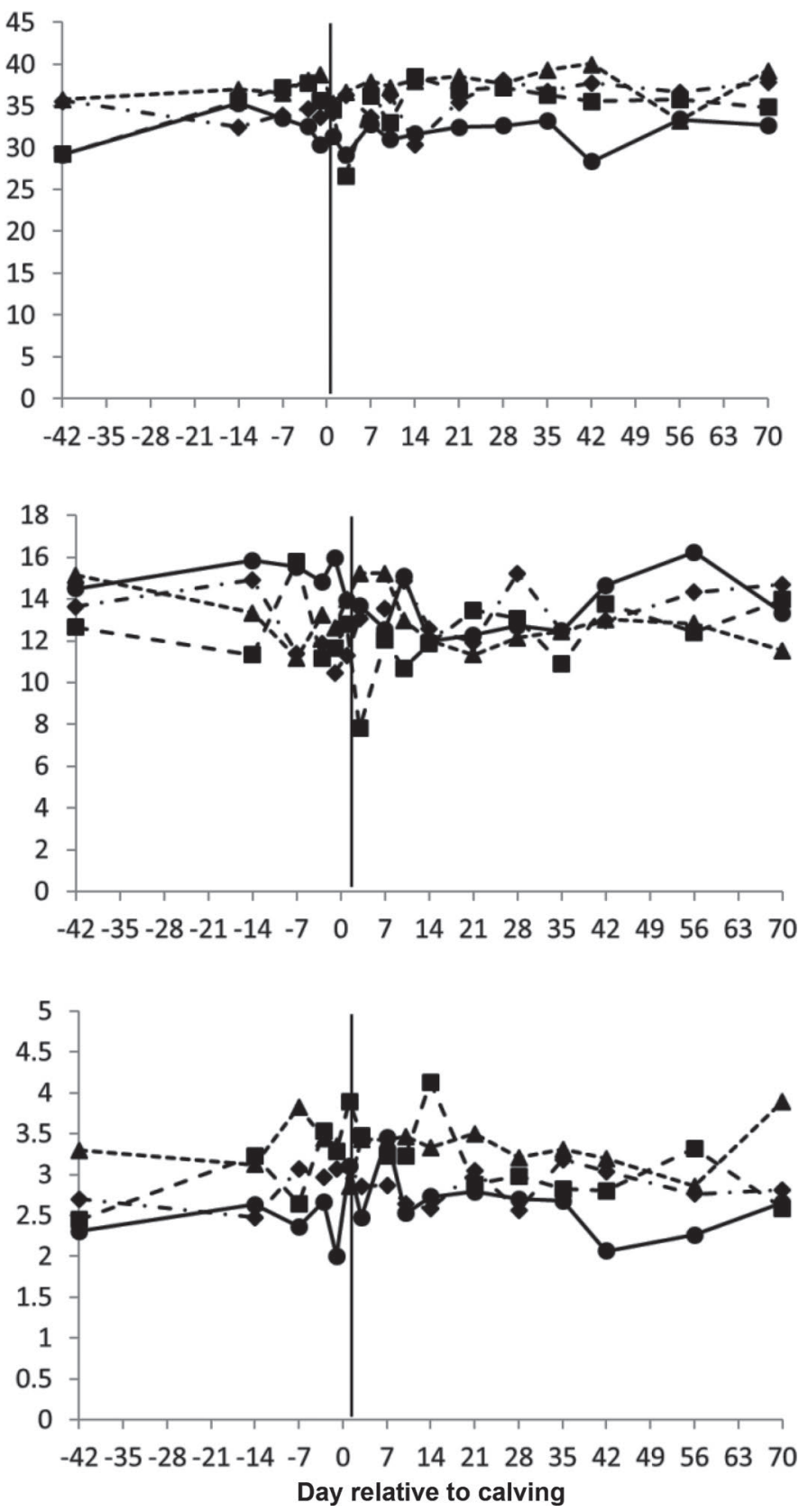

Figure 5. Mean proportion of $\mathrm{CD} 4^{+}$and $\mathrm{CD} 8^{+}$subpopulations of lymphocytes as well as the CD ratio of whole blood of cows in second (left side) and $\geq$ third (right side) parity (LSM). Groups included a control group ( $\mathrm{n}=16$; $\bullet$, solid line), a CLA group receiving $8.4 \mathrm{~g}$ of trans-10, cis-12 $\mathrm{CLA} / \mathrm{d}(\mathrm{n}=16 ; \boldsymbol{\square}$, long dashed line), a vitamin E group $(\mathrm{n}=15)$ receiving $2,327 \mathrm{IU}$ of vitamin $\mathrm{E} / \mathrm{d}(\boldsymbol{\Lambda}$, short dashed line), and a group ( $\mathrm{n}=$ 12) receiving both treatments ( $\bullet$ long dash-dotted line) from d -42 until 70 relative to calving. In the control group, 10 cows were in second and 6 in third or higher parity. In the CLA group, 9 cows were in second and 6 in third or higher parity. For the vitamin E group, this relationship was 10:5, whereas in the CLA + vitamin E group 5 cows were in second and 7 cows in third or higher parity. 



Figure 6. Mean basal and stimulated proportion and fluorescence intensity (MFI) of rhodamine (R)123+ population of total PMNL of cows in second (left side) and $\geq$ third (right side) parity (LSM). Groups included a control group $(\mathrm{n}=16$; $\boldsymbol{\bullet}$, solid line), a CLA group receiving $8.4 \mathrm{~g}$ of trans-10, cis-12 CLA/d ( $\mathrm{n}=16$; $\boldsymbol{\square}$, long dashed line), a vitamin $\mathrm{E}$ group $(\mathrm{n}=15)$ receiving $2,327 \mathrm{IU}$ of vitamin $\mathrm{E} / \mathrm{d}(\boldsymbol{\Lambda}$, short dashed line), and a group $(\mathrm{n}=12)$ receiving both treatments $(\bullet$, long dash-dotted line) from d -42 until 70 relative to calving. In the control group, 10 cows were in second and 6 in third or higher parity. In the CLA group, 9 cows were in second and 6 in third or higher parity. For the vitamin E group, this relationship was 10:5, whereas in the CLA + vitamin E group 5 cows were in second and 7 cows in third or higher parity. 
their function in higher-conditioned dairy cows during the transition period (mean BCS at d -42 was 3.7). Gillund et al. (2001) showed that cows with high body condition before parturition are at a particularly high risk p.p. for lipomobilization and, consequently, ketosis. Therefore, we chose the animal model proposed by Schulz et al. (2014), according to which cows sensitive to ketosis should be selected for the trial. This model was shown by Drong et al. (2016) to be suitable to investigate the efficacy of treatments on health variables of transitional dairy cows.

The present trial's serum concentrations of BHB, fatty acids, and glucose, as well as variables of lactation performance, were described in Schäfers et al. (2017a). According to Holtenius and Holtenius (1996), the type-II ketosis is characterized by an increase of BHB and fatty acids during the first 3 wk in early lactation, which in combination with stress might lead to a fatty liver. In our trial, however, cows did not develop fatty livers (Schäfers et al., 2017a). Contrary to the type-II ketosis, type-I ketosis occurs after 3 to 6 wk of lactation, with cows able to use ketone bodies to partially compensate for the decreased energy intake. Consequently, these animals do then not show symptoms related to liver stress. The cows in our trial were higher-conditioned (Schäfers et al., 2017a) and fed according to the chosen animal model, but they did not develop type-II ketosis (Holtenius and Holtenius, 1996). High concentrations of fatty acids and ketone bodies in early lactation accompanied with a fatty liver might be important for the development of diseases in transition dairy cows (Roche et al., 2009; Esposito et al., 2014). The activity of AST, GGT, and GLDH measured blood is suitable for assessing liver cell integrity (Bertoni and Trevisi, 2013). Sevinc et al. (2001) reported that elevated activities of AST and GGT are linked to fatty liver. During the present trial, the activities of these enzymes were in all groups within physiological range according to Kraft and Dürr (2005); therefore, we can conclude that liver cell integrity was not impaired. Consequently, it was not possible to show any effect of treatment on variables of clinical chemistry related to liver health.

The peak bilirubin concentration in our trial observed shortly after parturition exceeded the physiological concentration of $0.35 \mathrm{mg} / \mathrm{dL}$. Increased bilirubin concentrations might be attributed to prehepatic, hepatic, or posthepatic causes. Bertoni and Trevisi (2013) suggest that increased bilirubin concentrations around parturition are caused by inflammation, which is responsible for a reduced production of liver proteins. We assumed that, among the reduced liver proteins, enzymes responsible for excretion of bilirubin into bile were reduced as well and that, consequently, this excretion might be impaired. According to Bobe et al. (2004), increased bilirubin might also be an indicator of a decreased bile flow within the liver. Correlations between GGT and bilirubin were significant for the groups treated with CLA, whereas correlations between GGT and cholesterol were significant for all groups except the CLA + VE group. This might indicate a decreased bile flow, which we, however, did not particularly measure. As concentrations were within physiological values 14 $\mathrm{d}$ after parturition for cows in $\mathrm{Pa} 1$ and $28 \mathrm{~d}$ after parturition for cows in $\mathrm{Pa} 2$, we concluded that that the effect of inflammation around parturition on the production of liver proteins was more severe in older than in younger cows.

Hematological variables were influenced by day and, hence, by parturition rather than by treatment. A hemoconcentration caused by a reduced water intake around calving might be responsible for the peaks in hemoglobin and hematocrit. According to Shperling and Danon (1990), the MCV in humans increases with age. This increase is probably caused by a decreased lifespan of red blood cells, leading to an increased production of red blood cells. As young red blood cells have a higher volume, the MCV consequently increases as well. Generally, the values were within physiological ranges according to Kraft and Dürr (2005) for all groups during our trial. Therefore, we came to the conclusion that neither treatment nor parity elicited a negative effect on the red blood profile.

The increase in WBC toward calving is in line with literature (Zerbe et al., 2000; Drong et al., 2017). According to Quiroz-Rocha et al. (2009), the WBC of cows in 3rd or higher parity should be enhanced compared with cows in the 2nd parity before calving; this finding was not confirmed by the present results. Similar to Kelley et al. (2002) and Albers et al. (2003) in humans, as well as Song et al. (2005) in mice, we detected no influence of treatment with CLA on the white blood cell profile. Meydani et al. (1997) reported that vitamin E supplementation did not affect total quantity of B and $\mathrm{T}$ lymphocytes in humans, which is in accordance with our findings; however, supplementation with CLA and vitamin $\mathrm{E}$ might elicit a different effect in cows challenged by ketosis.

The subpopulations and functionality of immune cells were influenced by parturition and not by treatment or parity. Metabolic activity of PBMC was lowest around parturition, which is in accordance with the findings of Ishikawa (1987), Detilleux et al. (1994), Lessard et al. (2004), and Renner et al. (2012). The ability of PBMC to respond to stimulation showed in all groups the lowest values on $\mathrm{d} 7$ p.p., which is in accordance with the results by Hussen et al. (2011) and Renner et al. (2013). In the present trial, we observed no difference in SI increase after parturition, and that no effect of CLA 
supplementation could be found may be attributed to several factors. Though we did not analyze the fatty acid profile in PBMC, we assumed that a dose of 8.4 $\mathrm{g}$ of CLA/d for $112 \mathrm{~d}$ was sufficient to include trans10, cis-12 CLA into the fatty acid profile. Hussen et al. (2011) and Renner et al. (2012) reported a change of fatty acid profile at $5.7 \mathrm{~g}$ of CLA/d for $105 \mathrm{~d}$; Renner et al. (2012) also observed negative correlations between fatty acids and SI. In the present study, correlations between fatty acids and SI were not significant; therefore, we might conclude that fatty acid concentrations were not high enough to provoke a disrupting effect on PBMC. Peak fatty acid concentration in our study was $0.79 \mathrm{mmol} / \mathrm{L}$ at d 7 p.p. Lacetera et al. (2004) reported a decreased proliferation of PBMC from fatty acid concentrations of $1 \mathrm{mmol} / \mathrm{L}$ and above. Park and Pariza (1998) observed that commercial calf serum as used in the $\mathrm{AB}$ assay can contain significant amounts of trans10, cis-12 CLA itself, which might mask the effect of the exogenous CLA supplementation. According to Nugent et al. (2005), the effect of CLA on PBMC might also be attributed to the cis-9,trans-11 isomer. Those authors observed an influence of CLA when cows received 1.4 $\mathrm{g} / \mathrm{d}$ of cis-9,trans-11 CLA in an 80:20 mixture. The PBMC of cows that received $1 \mathrm{~g} / \mathrm{d}$ of cis-9,trans-11 CLA in a 50:50 mixture were not influenced; however, cows in our trial received a higher dose of $8.4 \mathrm{~g} / \mathrm{d}$ of $\mathrm{cis}^{-}$ 9,trans-11 CLA in a 50:50 mixture. Therefore, it might be possible that not the daily amount of cis-9,trans-11 CLA is crucial, but the ratio of both isomers.

Contrary to Hussen et al. (2011), who detected a decrease of CD4+ lymphocytes from d 21 p.p. on in animals treated with $5.7 \mathrm{~g}$ of CLA daily, we did not detect any changes in lymphocyte subpopulations. The observed distinct nadir of the R123+ proportion of granulocytes from 2 to $10 \%$ shortly after calving is in line with results described in literature (Dosogne et al., 1999; Rinaldi et al., 2008); and Drong et al. (2017) emphasized the importance of parturition for the oxidative system of the cow. The R123+-populations in cows in 3rd or higher parity were increased only from d 28 p.p. on. Consequently, we concluded that the ability of PMNL to elicit an oxidative burst reaction might be impaired in older cows compared with younger cows. This effect of aging is well described in literature for human PMNL (Niwa et al., 1989). As the oxidative burst of granulocytes is an important defense mechanism against pathogens, older cows might be more sensitive to infections. We did not observe any influence of supplementation. Ndiweni and Finch (1996) found in vitro that vitamin $\mathrm{E}$ increased chemotactic and phagocytic abilities as well as the production of superoxide of bovine PMNL. Politis et al. (1995, 2004) reported that doses of 3,000 IU/d of vitamin $\mathrm{E}$ increase the function of bovine PMNL. Gyang et al. (1984) compared the phagocytizing ability of cows supplemented with 1,000 IU of vitamin $\mathrm{E}$ and selenium to that of selenium-deficient cows and detected no difference in function of PMNL. Therefore, we can conclude that supplementation with 2,354 IU of vitamin E does not increase the function of PMNL to phagocyte pathogens and that a daily supplementation of at least 3,000 IU might be necessary. Kang et al. (2007) reported that trans-10, cis-12 CLA upregulates the PPAR $\gamma$-expression in porcine PBMC, which leads to an increased production of tumor necrosis factor- $\alpha$ and consequently improves the phagocytic capacity of PMNL. Furthermore, Kang and Yang (2008) observed that supplementation of trans-10,cis-12 CLA enhances the phagocytic capacity and oxidative burst activity in PMNL of dogs. Because vitamin $\mathrm{E}$ is a ligand at $\mathrm{PPAR} \gamma$, we assumed that supplementation of CLA and vitamin E might have an effect on the function of PMNL. As this is not the case, further studies are necessary to clarify stimulation mechanisms of bovine PMNL.

\section{CONCLUSIONS}

The aim of this study was to investigate the effects of treatment with CLA or vitamin $\mathrm{E}$ or a combination thereof on biochemical, hematological and immunological variables of dairy cows during the critical transition phase. Elevated BHB and fatty acid concentrations play an important role in the disruption of immune functions around calving. Though we applied an established animal model, which has been proven to increase the susceptibility for lipomobilization and ketosis, cows in the present trial did not show ketotic concentrations of BHB and fatty acids. Therefore, the potential to observe treatment effects might have been limited. However, we can conclude that the supplemented dose of vitamin $\mathrm{E}$ was not sufficient to counteract the immune suppression caused even in healthy cows by the event of parturition. Furthermore, we concluded that the immune function of older cows was more sensitive to the event of calving. Older cows might be more susceptible to inflammatory events, which might be caused by their impaired ability to produce liver proteins in the state of inflammation caused by the event of parturition.

\section{ACKNOWLEDGMENTS}

The authors thank the co-workers of the Institute of Animal Nutrition and the Experimental Station of the Institute of Animal Nutrition, Friedrich-Loeffler-Institut (FLI) in Braunschweig, Germany, for performing the experiment and analyses. The study was supported by BASF SE, Ludwigshafen, Germany. 


\section{REFERENCES}

Albers, R., R. P. J. van der Wielen, E. J. Brink, H. F. J. Hendriks, V. N. Dorovska-Taran, and I. C. M. Mohede. 2003. Effects of cis9, trans-11 and trans-10, cis-12 conjugated linoleic acid (CLA) isomers on immune function in healthy men. Eur. J. Clin. Nutr. 57:595-603. https://doi.org/10.1038/sj.ejcn.1601585.

Bassaganya-Riera, J., R. Hontecillas, and D. C. Beitz. 2002. Colonic anti-inflammatory mechanisms of conjugated linoleic acid. Clin. Nutr. 21:451-459. https://doi.org/10.1054/clnu.2002.0594.

Bernabucci, U., B. Ronchi, N. Lacetera, and A. Nardone. 2005. Influence of body condition score on relationships between metabolic status and oxidative stress in periparturient dairy cows. J. Dairy Sci. 88:2017-2026. https://doi.org/10.3168/jds.S0022 $-0302(05) 72878-2$.

Bertoni, G., and E. Trevisi. 2013. Use of the liver activity index and other metabolic variables in the assessment of metabolic health in dairy herds. Vet. Clin. North Am. Food Anim. Pract. 29:413-431.

Betteridge, D. J. 2000. What is oxidative stress? Metabolism 49(Suppl. 1):3-8.

Bobe, G., J. W. Young, and D. C. Beitz. 2004. Invited review: Pathology, etiology, prevention, and treatment of fatty liver in dairy cows. J. Dairy Sci. 87:3105-3124.

Burton, G. W., and M. G. Traber. 1990. Vitamin E: Antioxidant activity, biokinetics, and bioavailability. Annu. Rev. Nutr. 10:357-382.

Chen, W. H., Y. J. Li, M. S. Wang, Z. C. Kang, H. L. Huang, and H. M. Shaw. 2012. Elevation of tissue alpha-tocopherol levels by conjugated linoleic acid in C57BL/6J mice is not associated with changes in vitamin E absorption or alpha-carboxyethyl hydroxychroman production. Nutrition 28:59-66. https://doi.org/10.1016/ j.nut.2011.04.006.

Contreras, G. A., and L. M. Sordillo. 2011. Lipid mobilization and inflammatory responses during the transition period of dairy cows. Comp. Immunol. Microbiol. Infect. Dis. 34:281-289.

Dahlgren, C., and A. Karlsson. 1999. Respiratory burst in human neutrophils. J. Immunol. Methods 232:3-14.

Detilleux, J. C., K. J. Koehler, A. Freeman, M. E. Kehrli, and D. H. Kelley. 1994. Immunological parameters of periparturient holstein cattle: Genetic variation. J. Dairy Sci. 77:2640-2650.

Dosogne, H., C. Burvenich, A. Freeman, M. Kehrli Jr., J. Detilleux, J. Sulon, J.-F. Beckers, and D. Hoeben. 1999. Pregnancy-associated glycoprotein and decreased polymorphonuclear leukocyte function in early post-partum dairy cows. Vet. Immunol. Immunopathol. $67: 47-54$.

Drong, C., U. Meyer, D. von Soosten, J. Frahm, J. Rehage, G. Breves, and S. Danicke. 2016. Effect of monensin and essential oils on performance and energy metabolism of transition dairy cows. J. Anim. Physiol. Anim. Nutr. (Berl.) 100:537-551. https://doi.org/ 10.1111/jpn.12401.

Drong, C., U. Meyer, D. von Soosten, J. Frahm, J. Rehage, H. Schirrmeier, M. Beer, and S. Danicke. 2017. Effects of monensin and essential oils on immunological, haematological and biochemical parameters of cows during the transition period. J. Anim. Physiol. Anim. Nutr. (Berl.) 101:791-806. https://doi.org/10.1111/jpn .12494

Esposito, G., P. C. Irons, E. C. Webb, and A. Chapwanya. 2014. Interactions between negative energy balance, metabolic diseases, uterine health and immune response in transition dairy cows. Anim. Reprod. Sci. 144:60-71

Gessner, D. K., E. Most, G. Schlegel, K. Kupczyk, F. Schwarz, and K. Eder. 2015. Concentrations of retinol and tocopherols in the milk of cows supplemented with conjugated linoleic acid. J. Anim. Physiol. Anim. Nutr. (Berl.) 99:1039-1046. https://doi.org/10 $.1111 /$ jpn.12325.

GfE. 2001. Empfehlung zur Energie- und Nährstoffversorgung von Milchkühen und Aufzuchtrindern. DLG-Verlag, Frankfurt am Main, Germany.

GfE. 2008. Communications of the committee for requirement standards of the society of nutrition physiology: New equations for predicting metabolisable energy of grass and maize products for ruminants. Proc. Soc. Nutr. Physiol. 17:191-198.
GfE. 2009. New equations for predicting metabolisable energy of compound feeds for cattle. Proc. Soc. Nutr. Physiol. 18:143-146.

Gillund, P., O. Reksen, Y. Gröhn, and K. Karlberg. 2001. Body condition related to ketosis and reproductive performance in Norwegian dairy cows. J. Dairy Sci. 84:1390-1396. https://doi.org/10.3168/ jds.S0022-0302(01)70170-1.

Goff, J. P., and R. L. Horst. 1997. Physiological changes at parturition and their relationship to metabolic disorders. J. Dairy Sci 80:1260-1268.

Grummer, R. R., P. C. Hoffman, M. L. Luck, and S. J. Bertics. 1995. Effect of prepartum and postpartum dietary energy on growth and lactation of primiparous cows. J. Dairy Sci. 78:172-180. https:// doi.org/10.3168/jds.S0022-0302(95)76627-9.

Gyang, E. O., J. Stevens, W. Olson, S. Tsitsamis, and E. Usenik. 1984. Effects of selenium-vitamin E injection on bovine polymorphonucleated leukocytes phagocytosis and killing of Staphylococcus aureus. Am. J. Vet. Res. 45:175-177.

Hiss, S., M. Mielenz, R. M. Bruckmaier, and H. Sauerwein. 2004. Haptoglobin concentrations in blood and milk after endotoxin challenge and quantification of mammary Hp mRNA expression. J. Dairy Sci. 87:3778-3784.

Hoeben, D., R. Heyneman, and C. Burvenich. 1997. Elevated levels of $\beta$-hydroxybutyric acid in periparturient cows and in vitro effect on respiratory burst activity of bovine neutrophils. Vet. Immunol. Immunopathol. 58:165-170.

Holtenius, P., and K. Holtenius. 1996. New aspects of ketone bodies in energy metabolism of dairy cows: A review. Zentralbl. Veterinarmed. A 43:579-587.

Hussen, J., S. Dänicke, and H. Schuberth. 2011. The effect of a long term dietary supplementation with conjugated linoleic acid (CLA) on the composition of bovine peripheral blood mononuclear cells (PBMC) and the concentration of IgG isotypes in blood and milk. Page 85 in Proc. Soc. Nutr. Physiol.

Ishikawa, H. 1987. Observation of lymphocyte function in perinatal cows and neonatal calves. Nihon Juigaku Zasshi 49:469-475.

Japanese Pharmacopoeia Committee. 2011. The Japanese Pharmacopoeia. 16th ed. The Society of Japanese Pharmacopoeia, Tokyo, Japan.

Kang, J.-H., G.-S. Lee, E.-B. Jeung, and M.-P. Yang. 2007. Trans-10, cis-12-conjugated linoleic acid increases phagocytosis of porcine peripheral blood polymorphonuclear cells in vitro. Br. J. Nutr. 97:117-125.

Kang, J.-H., and M.-P. Yang. 2008. In vitro evaluation of the effect of trans-10, cis-12 conjugated linoleic acid on phagocytosis by canine peripheral blood polymorphonuclear neutrophilic leukocytes exposed to methylprednisolone sodium succinate. Am. J. Vet. Res. 69:494-500.

Kelley, D. S., J. M. Warren, V. A. Simon, G. Bartolini, B. E. Mackey, and K. L. Erickson. 2002. Similar effects of c9, t11-CLA and t10,c12-CLA on immune cell functions in mice. Lipids 37:725-728. https://doi.org/10.1007/s11745-002-0954-7.

Kraft, W., and U. Dürr. 2005. Klinische Labordiagnostik in der Tiermedizin. Schattauer, Stuttgart, Germany.

Lacetera, N., D. Scalia, U. Bernabucci, B. Ronchi, D. Pirazzi, and A. Nardone. 2005. Lymphocyte functions in overconditioned cows around parturition. J. Dairy Sci. 88:2010-2016.

Lacetera, N., D. Scalia, O. Franci, U. Bernabucci, B. Ronchi, and A. Nardone. 2004. Short communication: Effects of nonesterified fatty acids on lymphocyte function in dairy heifers. J. Dairy Sci. 87:1012-1014.

LeBlanc, S. J., K. D. Lissemore, D. F. Kelton, T. F. Duffield, and K. E. Leslie. 2006. Major advances in disease prevention in dairy cattle. J. Dairy Sci. 89:1267-1279.

Lessard, M., N. Gagnon, D. L. Godson, and H. V. Petit. 2004. Influence of parturition and diets enriched in n- 3 or $n-6$ polyunsaturated fatty acids on immune response of dairy cows during the transition period. J. Dairy Sci. 87:2197-2210. https://doi.org/10 .3168/jds.S0022-0302(04)70040-5.

Littell, R. C., P. R. Henry, and C. B. Ammerman. 1998. Statistical analysis of repeated measures data using SAS procedures. J. Anim. Sci. 76:1216-1231. 
Mallard, B. A., J. C. Dekkers, M. J. Ireland, K. E. Leslie, S. Sharif, C. L. Vankampen, L. Wagter, and B. N. Wilkie. 1998. Alteration in immune responsiveness during the peripartum period and its ramification on dairy cow and calf health. J. Dairy Sci. 81:585-595. https://doi.org/10.3168/jds.S0022-0302(98)75612-7.

Meydani, S. N., M. Meydani, and J. B. Blumberg. 1997. Vitamin E supplementation and in vivo immune response in healthy elderly subjects: A randomized controlled trial. JAMA 277:1380-1386. https://doi.org/10.1001/jama.1997.03540410058031.

Mielenz, M., B. Mielenz, S. Singh, C. Kopp, J. Heinz, S. Häussler, and H. Sauerwein. 2013. Development, validation, and pilot application of a semiquantitative Western blot analysis and an ELISA for bovine adiponectin. Domest. Anim. Endocrinol. 44:121-130.

Miller, J. K., E. Brzezinska-Slebodzinska, and F. Madsen. 1993. Oxidative stress, antioxidants, and animal function. J. Dairy Sci $76: 2812-2823$.

Nakamura, Y. K., and S. T. Omaye. 2010. Lipophilic compound-mediated gene expression and implication for intervention in reactive oxygen species (ROS)-related diseases: Mini-review. Nutrients 2:725-736. https://doi.org/10.3390/nu2070725.

Ndiweni, N., and J. M. Finch. 1996. Effects of in vitro supplementation with $\alpha$-tocopherol and selenium on bovine neutrophil functions: implications for resistance to mastitis. Vet. Immunol. Immunopathol. 51:67-78.

Niwa, Y., T. Kasama, Y. Miyachi, and T. Kanoh. 1989. Neutrophil chemotaxis, phagocytosis and parameters of reactive oxygen species in human aging: Cross-sectional and longitudinal studies. Life Sci. 44:1655-1664. https://doi.org/10.1016/0024-3205(89)90482-7.

Nugent, A. P., H. M. Roche, E. J. Noone, A. Long, D. K. Kelleher, and M. J. Gibney. 2005. The effects of conjugated linoleic acid supplementation on immune function in healthy volunteers. Eur. J. Clin. Nutr. 59:742-750. https://doi.org/10.1038/sj.ejcn.1602132.

O'Shea, M., J. Bassaganya-Riera, and I. C. M. Mohede. 2004. Immunomodulatory properties of conjugated linoleic acid. Am. J. Clin. Nutr. 79:1199S-1206S.

Park, Y., and M. W. Pariza. 1998. Evidence that commercial calf and horse sera can contain substantial amounts of trans-10,cis-12 conjugated linoleic acid. Lipids 33:817. https://doi.org/10.1007/ s11745-998-0275-x.

Politis, I., I. Bizelis, A. Tsiaras, and A. Baldi. 2004. Effect of vitamin E supplementation on neutrophil function, milk composition and plasmin activity in dairy cows in a commercial herd. J. Dairy Res. $71: 273-278$.

Politis, I., M. Hidiroglou, T. Batra, J. Gilmore, R. Gorewit, and H. Scherf. 1995. Effects of vitamin E on immune function of dairy cows. Am. J. Vet. Res. 56:179-184.

Quiroz-Rocha, G. F., S. J. LeBlanc, T. F. Duffield, D. Wood, K. E. Leslie, and R. M. Jacobs. 2009. Reference limits for biochemical and hematological analytes of dairy cows one week before and one week after parturition. Can. Vet. J. 50:383.

Renner, L., S. Kersten, A. Duevel, H. J. Schuberth, and S. Danicke. 2013. Effects of cis-9, trans-11 and trans-10, cis-12 conjugated linoleic acid, linoleic acid, phytanic acid and the combination of various fatty acids on proliferation and cytokine expression of bovine peripheral blood mononuclear cells. Nutrients 5:2667-2683. https://doi.org/10.3390/nu5072667.

Renner, L., J. Pappritz, R. Kramer, S. Kersten, G. Jahreis, and S. Danicke. 2012. Fatty acid profile and proliferation of bovine blood mononuclear cells after conjugated linoleic acid supplementation. Lipids Health Dis. 11:63. https://doi.org/10.1186/1476-511X-11 $-63$.

Renner, L., A. Schwabe, S. Döll, M. Höltershinken, and S. Dänicke. 2011. Effect of rare earth elements on beef cattle growth performance, blood clinical chemical parameters and mitogen stimulated proliferation of bovine peripheral blood mononuclear cells in vitro and ex vivo. Toxicol. Lett. 201:277-284.
Rimbach, G., A. M. Minihane, J. Majewicz, A. Fischer, J. Pallauf, F. Virgli, and P. D. Weinberg. 2002. Regulation of cell signalling by vitamin E. Proc. Nutr. Soc. 61:415-425. https://doi.org/10.1079/ PNS2002183.

Rinaldi, M., P. Moroni, M. J. Paape, and D. D. Bannerman. 2008. Differential alterations in the ability of bovine neutrophils to generate extracellular and intracellular reactive oxygen species during the periparturient period. Vet. J. 178:208-213. https://doi.org/10 $.1016 / j . t v j 1.2007 .07 .030$

Roche, J. R., N. C. Friggens, J. K. Kay, M. W. Fisher, K. J. Stafford, and D. P. Berry. 2009. Invited review: Body condition score and its association with dairy cow productivity, health, and welfare. J. Dairy Sci. 92:5769-5801.

Scalia, D., N. Lacetera, U. Bernabucci, K. Demeyere, L. Duchateau, and C. Burvenich. 2006. In vitro effects of nonesterified fatty acids on bovine neutrophils oxidative burst and viability. J. Dairy Sci. $89: 147-154$

Schäfers, S., U. Meyer, D. von Soosten, L. Hüther, C. Drong, K. Eder, E. Most, A. Tröscher, W. Pelletier, A. Zeyner, and S. Dänicke. 2017b. Influence of conjugated linoleic acids and vitamin $\mathrm{E}$ on milk fatty acid composition and concentrations of vitamin A and $\alpha$-tocopherol in blood and milk of dairy cows. J. Anim. Physiol. Anim. Nutr. (Berl.) https://doi.org/10.1111/jpn.12762.

Schäfers, S., D. von Soosten, U. Meyer, C. Drong, J. Frahm, J. Kluess, C. Raschka, J. Rehage, A. Tröscher, W. Pelletier, and S. Dänicke. 2017. Influence of conjugated linoleic acid and vitamin $\mathrm{E}$ on performance, energy metabolism, and change of fat depot mass in transitional dairy cows. J. Dairy Sci. 100:3193-3208. https://doi .org/10.3168/jds.2016-11882.

Schulz, K., J. Frahm, U. Meyer, S. Kersten, D. Reiche, J. Rehage, and S. Danicke. 2014. Effects of prepartal body condition score and peripartal energy supply of dairy cows on postpartal lipolysis, energy balance and ketogenesis: An animal model to investigate subclinical ketosis. J. Dairy Res. 81:257-266. https://doi.org/10 .1017/S0022029914000107.

Sevinc, M., A. Basoglu, F. M. Birdane, and M. Boydak. 2001. Liver function in dairy cows with fatty liver. Rev. Med. Vet. (Toulouse) 152:297-300.

Shperling, T., and D. Danon. 1990. Age population distribution of erythrocytes in young and old healthy donors. Exp. Gerontol. $25: 413-422$.

Song, H. J., I. Grant, D. Rotondo, I. Mohede, N. Sattar, S. D. Heys, and K. W. J. Wahle. 2005. Effect of CLA supplementation on immune function in young healthy volunteers. Eur. J. Clin. Nutr. 59:508-517.

Sordillo, L. M., and S. L. Aitken. 2009. Impact of oxidative stress on the health and immune function of dairy cattle. Vet. Immunol. Immunopathol. 128:104-109.

Suriyasathaporn, W., A. J. J. M. Daemen, E. N. Noordhuizen-Stassen, S. J. Dieleman, M. Nielen, and Y. H. Schukken. 1999. Beta-hydroxybutyrate levels in peripheral blood and ketone bodies supplemented in culture media affect the in vitro chemotaxis of bovine leukocytes. Vet. Immunol. Immunopathol. 68:177-186.

Trevisi, E., G. Bertoni, R. Lombardelli, and A. Minuti. 2013. Relation of inflammation and liver function with the plasma cortisol response to adrenocorticotropin in early lactating dairy cows. J. Dairy Sci. 96:5712-5722.

VDLUFA. 1993. Handbuch der Landwirtschaftlichen Versuchs- und Untersuchungsmethodik (VDLUFA-Methodenbuch). Vol. III. VDLUFA-Verlag, Darmstadt, Germany.

Zerbe, H., N. Schneider, W. Leibold, T. Wensing, T. Kruip, and H. Schuberth. 2000. Altered functional and immunophenotypical properties of neutrophilic granulocytes in postpartum cows associated with fatty liver. Theriogenology 54:771-786. 